\title{
Effect of Inter Row Spacing with or Without Weed Control in Wheat (Triticum aestivum $\mathrm{L}$.)
}

\author{
F.S. Abd El-Samie, Ekram A. Megawer, A.A.A. Mekdad and Sara M. Mohamed \\ Agronomy Department, Faculty of Agriculture, Fayoum University, Fayoum, Egypt.
}

$\mathbf{T}$

WO FIELD experiments were carried out at the Experimental Farm of the Faculty of Agriculture (Demo), Fayoum University, during 2016/2017 and 2017/2018 seasons, to study the effect of row spacing and weed control treatments on yield and its components of wheat plants and its associated weeds. The experimental design was split- plot arrangement in randomized complete block design with three replications where row spacing was considered as the main plot, weeds control treatments arranged in the sub-plot. Results indicated that row spacing treatments were significantly on annual weeds $\left(\mathrm{g} / \mathrm{m}^{2}\right)$ and yield components in both seasons. Narrow row spacing at $15 \mathrm{~cm}$ gave the highest values of plant height at harvest $(\mathrm{cm})$, number of spikes $/ \mathrm{m}^{2}$, grain and biological yield (ton/fad) in both seasons.

The results indicated that the narrowest row spacing under this study $(15 \mathrm{~cm})$ decreased the dry weight of total weeds by 42.22 and $43.29 \mathrm{~g} / \mathrm{m}^{2}$ in first and second seasons, respectively, compared to wide row spacing. Weed control treatments were significant on yield and yield components in both seasons. The herbicides treatment with Granstar+Topik gave the highest values for all traits under these study in both seasons. The interaction between row spacing and weed control treatments were reacted significantly on annual weeds $\left(\mathrm{g} / \mathrm{m}^{2}\right)$ in both seasons. Wheat sown under narrow row spacing $15 \mathrm{~cm}$ and applying Granstar+Topik herbicides achieved the best crop of wheat under the experiment conditions.

Keywords: Wheat, Row spacing, Weeds, Herbicides, Yield and its components.

\section{Introduction}

Wheat (Triticum aestivum L.) is a major cereal crop in Egypt and over the entire world. In 2015 wheat cultivated area in Egypt was about 3.3 million feddan $\left(4200 \mathrm{~m}^{2}\right)$ which producing about 9 million tons. However, it covers less than 55\% of local consumption demand which reflects on the demand import about $45 \%$ of wheat grains from abroad (FAO, 2016).

Therefore, a great attention should be paid to raise wheat productivity either by increasing the cultivated area or maximizing yield per unit area in order to reduce the gap between its production and consumption. Increasing the cultivated area within the old land of the Nile Valley, however, in which wheat face severe competition with other winter crops especially clover. So, calls for the cultivation of wheat additional parcels in the newly reclaimed soil.

Whereas, maximizing yield per unit area may be happen through the use of best agricultural transactions, including weed-control treatments and Manipulating row spacing.

Row spacing affects crop yield as it not only determines the optimum crop stand, but also facilitates inter-culture and convenient herbicide application for effective and efficient weed control. In addition, proper row spacing is important for maximizing light interception, penetration, light distribution in crop canopy and average light utilization efficiency of the leaves in the canopy and, thus, affects yield of a crop (Hussain et al., 2003). Narrow row spacing in wheat caused suppression of weeds by increasing ground cover, leaf area, light interception and even spatial plant distribution (Drews et al., 2009 and Babaei \& Saeedipour, 2015).

Weeds are one of the major constraints in wheat production as they reduce productivity due to competition, allelopathy, by providing habitats for pathogens as well as serving as alternate host for various insects and fungi and increase harvest cost. Studies indicated that crop losses

"Corresponding author email: sm1659@fayoum.edu.eg 
due to weed competition throughout the world as a whole, are greater than those resulting from the combined effect of insect pests and diseases. It causes yield reduction in wheat from $10-65 \%$ (Genene \& Habtamu, 2001).

Weed control is one of the essential cultural practices for raising wheat. Shaban et al. (2009) indicated that the reduction in wheat yield due to the broad-leaves weeds competition were 27.5 and $19.2 \%$; for grassy weeds 43.7 and $33.2 \%$, but for total annual weeds 46.8 and $46.4 \%$ in $2006 / 07$ and 2007/08 seasons, respectively. Manual weeding done twice at 15 and 30 days stage was found most effective in reducing weed dry matter accumulation (Sharma \& Singh, 2011).

Weed control treatments were significantly reduced dry weight of grassy, broad-leaved and total weeds $\left(\mathrm{g} / \mathrm{m}^{2}\right)$ in both seasons compared to unweeded control ( $\mathrm{T}_{6}$ ) (Mahmud et al., 2016).

Chemical weed control in wheat fields by post - emergence herbicides such as Granstar and Topik have been used to control weeds in wheat fields in Egypt to improve wheat productivity through elimination of weed competition (Soliman et al., 2011 and Shehzad et al., 2012).

Therefore, this investigation was established to study the effect of different row spacing and weed control treatments and their interactions on yield and its components of wheat plants and associated weeds.

\section{Materials and Methods}

\section{Experimental site and plant materials}

Tow field experiments were conducted during 2016/2017 and 2017/2018 winter seasons at the Experimental Farm of Faculty of Agriculture, at Demo, Fayoum University. The objective of this research was to study the effect of row spacing, weed control treatments and their interactions on Sids 12 winter bread wheat (Triticum aestivum L.) variety and associated weeds.

\section{Layout and experimental design}

Each experiment included 15 treatments arranged in a split- plot design with four replicates the treatments were the combinations of:

1. Plot area was $10.5 \mathrm{~m}^{2}(3 \times 3.5 \mathrm{~m})$.

2. Three row spacing treatments (allocated in the main plots) were 15,20 and $25 \mathrm{~cm}$ between each row.

3. Five weed control treatments (laid out in the sub plots), i.e.

- Unweeded (control) treatment $\left\{\mathrm{W}_{1}\right\}$.

- Hand weeding twice at 30 and 45 days after planting $\left\{\mathrm{W}_{2}\right\}$.

- Grass weeds herbicide (Table 1) Clodinafop-propargy (Topik) Formulated by Syngenta Crop protection AG company: At the rate of $140 \mathrm{~g} / \mathrm{fad}$, as post emergence $\left\{\mathrm{W}_{3}\right\}$.

- Broad leaf herbicide (Table 1) tribenuron - methyl (Granstar) formulated for and distributed by DuPont (New Zealand): at the rate of $8 \mathrm{~g} / \mathrm{fad}$, applied as post emergence $\left\{\mathrm{W}_{4}\right\}$.

- Granstar at the rate $8 \mathrm{~g} / \mathrm{fad}+$ Topik at the rate $140 \mathrm{~g} / \mathrm{fad}\left\{\mathrm{W}_{5}\right\}$.

Granstar was sprayed as post emergence at 20 days after sowing. While Topik was sprayed as post emergence at 30 days after sowing.

\section{Cultural practices}

Winter Wheat variety Sids 12 was obtained from the Wheat Department, Field Crops Institute Research, Agricultural Research Center, Giza, Egypt. It was sowed at 15 and 21 of November and harvested in 25 and 30 April in the first and second seasons, respectively. While seeding rate was $50 \mathrm{~kg} / \mathrm{fad}$. The preceding summer crop was maize (Zea mays L.) in both seasons. In the two experiments $\mathrm{N}$ fertilizer was added on the form of ammonium nitrate $(33.5 \% \mathrm{~N})$ at rate of $80 \mathrm{~kg} \mathrm{~N} / \mathrm{fad}$, was added in three doses. The first dose $(20 \mathrm{~kg} \mathrm{~N} / \mathrm{fad})$ was added at sowing time, the second dose $(30 \mathrm{~kg} \mathrm{~N} / \mathrm{fad})$ was added before the first irrigation (21 days after sowing) and the third dose (30kg N/fad) was added (21 days after the first irrigation). Phosphorus fertilizer was applied in the form of calcium superphosphate $\left(15.5 \% \mathrm{P}_{2} \mathrm{O}_{5}\right)$ at the rate of $150 \mathrm{~kg} \mathrm{P}_{2} \mathrm{O}_{5} / \mathrm{fad}$, added during the soil preparation. Potassium fertilizer was applied before sowing (during seedbed preparation) at rate of $50 \mathrm{~kg} / \mathrm{fad}$, in the form of potassium sulphate $\left(48 \% \mathrm{~K}_{2} \mathrm{O}\right)$. The first Irrigation was applied at 21 days after sowing then plants were irrigated every 21 days till the dough stage. All other agricultural treatments for wheat production were carried out as recommended by the Ministry of Agriculture. 
TABLE 1. Trade, common and chemical names of the herbicides used in the study.

\begin{tabular}{lll}
\hline Trade name & Common name & \multicolumn{1}{c}{ Chemical name } \\
\hline Topik 15\% WP & Clodinafop-propargyl & $\begin{array}{l}\text { \{2-propnil (®)-2-[4-(5-chloro-3-fluoro-2-pyridnyloxy) } \\
\text { phenoxy]-propionate }\end{array}$ \\
Granstar 75\% Df & Tribenuron-methyl & $\begin{array}{l}\text { [Methyl 2-(N- (4-methoxy-6-methyl-1, 3, 5 triazin 2- } \\
\text { cultivars [13, 14].Y) methylamine) caronyl) amino) sulful) } \\
\text { benzoate. }\end{array}$ \\
\hline
\end{tabular}

\section{Soil analysis}

The soil texture was sandy loam with organic matter of 0.64 and $0.62 \%$ ) Ec of 3.60 and $3.59, \mathrm{pH}$ values of 7.51 and $7.56, \mathrm{Ca} \mathrm{Co}_{3}$ of 7.21 and 7.30 and total nitrogen of 0.05 in both seasons.

\section{Field sampling and data collection \\ Weeds}

The dominant weeds species in the present study were recorded : (Beta vulgaris L., Rumex dentatus L. and Medicago hispida) as annual broadleaved weeds . Avena spp (Wild oats) and Phalaris sp. (Canary grass) as annual grassy weeds. Weeds were hand pulled from one square meter randomly of each plot 60 DAS (days after sowing), then classified into two groups, i.e. broad-leaved weeds and grassy weeds. Weeds were air dried for 3 days and dried on oven at $70^{\circ} \mathrm{C}$ for $24 \mathrm{~h}$. The dry weight of each individual group of weeds as well as the total weeds were recorded.

\section{Wheat}

At harvest time when the plants were completely senesced, five guarded plants were taken at random from each sub- plot in the four replications to determine some agronomic data including:

1 - Plant height at harvest $(\mathrm{cm})$.

2- Number of tillers/plant.

3- Number of spikes/plant.

4- Spike length (cm).

5- Number of spikelets/spike.

6- Number of grain/spike.

7-Grains weight/plant (g).

8-1000-grain weight (g).

9- Biological yield (ton/fad).

10- Grain yield (ton/fad).

11- Harvest index (\%) which was estimated as: Grain yield/Biological yield x 100 .

\section{Statistical analysis}

All obtained data were statistically analyzed according to the technique of analysis of variance (ANOVA) for the spilt-plot design as outlined by Gomez \& Gomez (1984), using MSTAT statistical package (MSTAT-C) developed by Department of Crop and Soil Sciences, Michigan State University, East Lansing, MI 48824 USA. Least Significant Difference (LSD, at 5\% level of probability) was used to test the differences between treatments mean.

\section{Results and Descusion}

Weeds

Data presented in Table 2 show the dry weight of annual weeds as affected by row spacing, weed control treatments and their interaction at 60 days after wheat sowing.

Growth of all annual weed groups, i. e. broadleaf, grass and total, was markedly inhibited with narrow row spacing than wide row spacing. However, $15 \mathrm{~cm}$ apart- rows was the most efficient in all cases. These results are in agreement with those recorded by Tompkins et al. (1991) and Hussain et al. (2003). Also, all weed control treatments caused markedly inhibition in dry weight of all weed groups compared with unweeded (control). Where, hand weeding twice $\left(\mathrm{W}_{2}\right)$ followed by Granstar + Topik $\left(\mathrm{W}_{5}\right)$ treatment was the most efficient among all treatments in both seasons as a total weeds $\left(36.15\right.$ and $\left.34.82 \mathrm{~g} / \mathrm{m}^{2}\right)$, respectively.

These results are in agreement with those recorded by Mahmud et al. (2016) and Mekdad (2015), at the experimental farm of faculty of agriculture, at Demo, Fayoum university (in the same conditions), reported that the adopted weeding regimes exerted highly significant effects on all of the assessed growth, seed yield attributes and seed and seed oil yields parameters for sesame crop and both weeds biomass and weed control efficiency as well. Furthermore, hand-hoeing practice achieved higher figures of sesame growth and yield parameters and monetary returns. 
TABLE 2. Effect of row spacing, weed control treatments and their interaction on dry weight of broad, grassy and total weeds $\left(\mathrm{g} / \mathrm{m}^{2}\right)$ in $2016 / 2017$ and $2017 / 2018$ seasons.

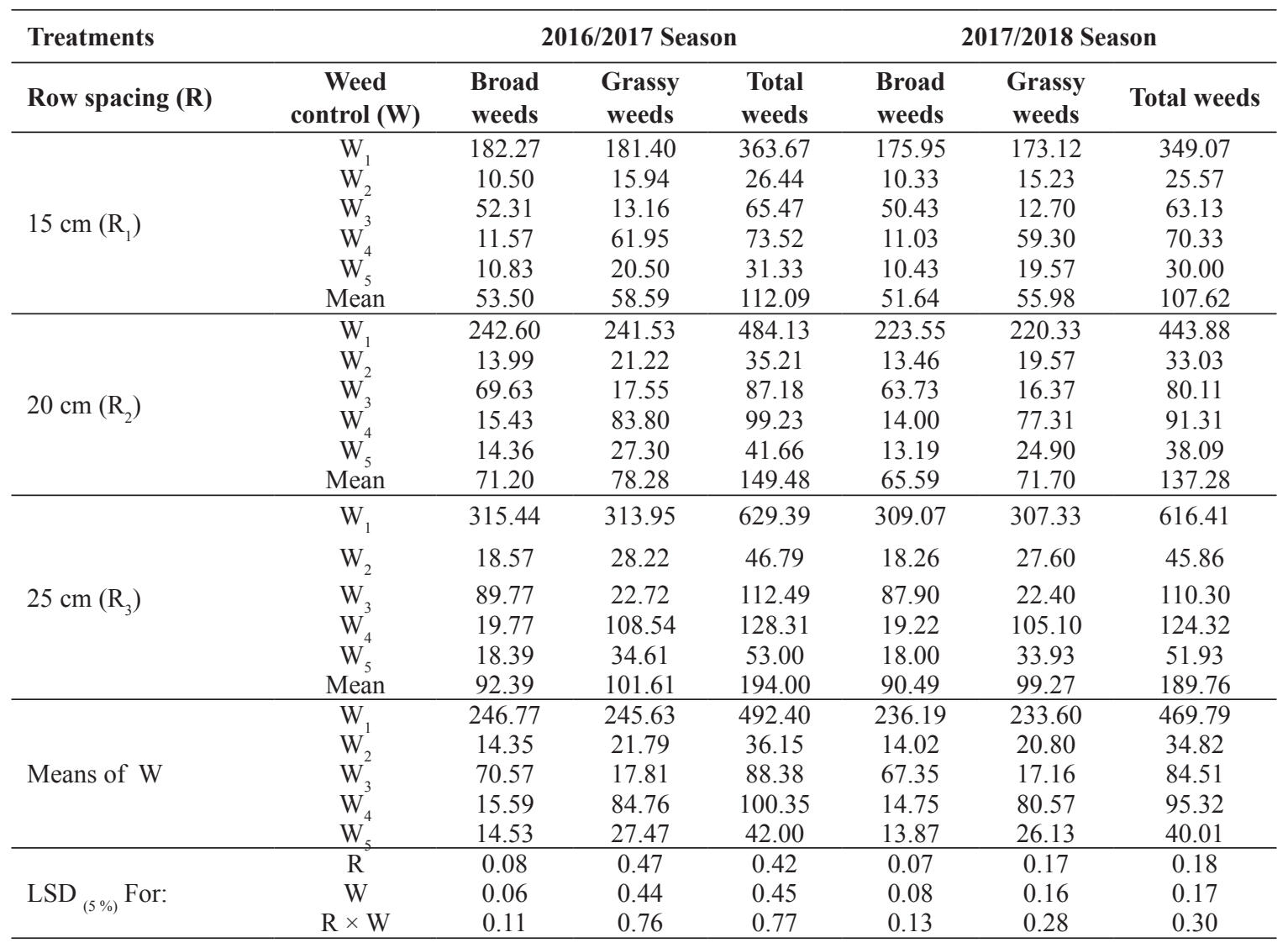

$\mathrm{W}_{1}=$ Unweeded (control), $\mathrm{W}_{2}=$ Hand weeding, $\mathrm{W}_{3}=$ Topik herbicide, $\mathrm{W}_{4}=$ Granstar herbicide, $\mathrm{W}_{5}=$ Granstar + Topik.

When wheat was sown at row spacing of $15 \mathrm{~cm}$ reduced total weed growth by $25.01 \%$ and $42.22 \%$ than when rows spaced 20 and $25 \mathrm{~cm}$, respectively in the first season, and by $21.61 \%$ and $43.29 \%$ in the second season. The interference ability of wheat against the associated weeds is expected to be more and more with the increase in the crop density, so decreasing weed growth. Sharma \& Singh (2011) mentioned that greater crop density results in reduced weed growth.

The interaction between row spacing and weed control treatments had marked effects on growth of each weed group (Table 2). The major inhibition effect was provided by application of hand weeding twice $\left(\mathrm{W}_{2}\right)$ followed by Granstar + Topik $\left(\mathrm{W}_{5}\right)$ with either $15 \mathrm{~cm}$ sown rows for dry broad-leaf and total weeds. The poorest combination in all cases was noted in the unweeded plots with $25 \mathrm{~cm}$ parted rows.

Wheat

Results of wheat criteria as affected by row spacing, weed control treatments and their interaction are shown in Tables 3 and 4.

Each shortening in row spacing increased plant height $(\mathrm{cm})$ at harvest

Weeding treatments improved wheat plant height, yield and yield components over the unweeding one. The reduction in weed infestation, i. e. less weed interference against wheat plants, achieved by the weeded treatments may be responsible for the recorded improvement in the crop growth and as a result in yield increases. Bibi et al. (2008) found that Topik 15 WP treated plots exhibited the best performance with minimum weed density $\left(74.75 \mathrm{~m}^{-2}\right)$ and weed fresh biomass $(1875 \mathrm{~kg}$ $\left.\mathrm{ha}^{-1}\right)$ compared to the weedy control $\left(387.3 \mathrm{~m}^{-2}\right.$ and $\left.5313 \mathrm{~kg} \mathrm{ha}^{-1}\right)$. Maximum grain yield $(3656 \mathrm{~kg}$ $\left.\mathrm{ha}^{-1}\right)$, number of tillers $\left(215.6 \mathrm{~m}^{-2}\right)$ and plant height $(56.53 \mathrm{~cm})$ at maturity were recorded in Topik 15 WP. 


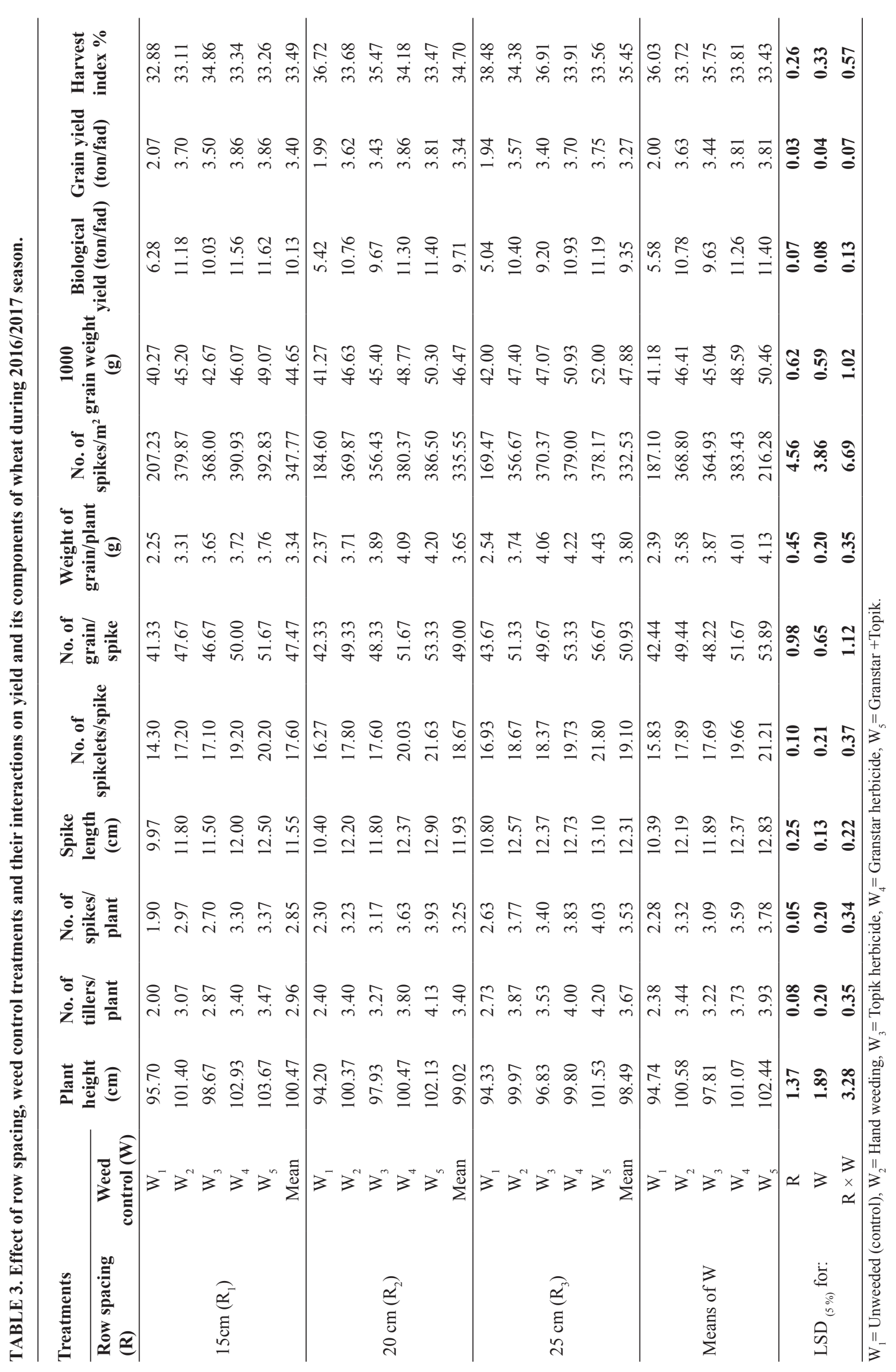




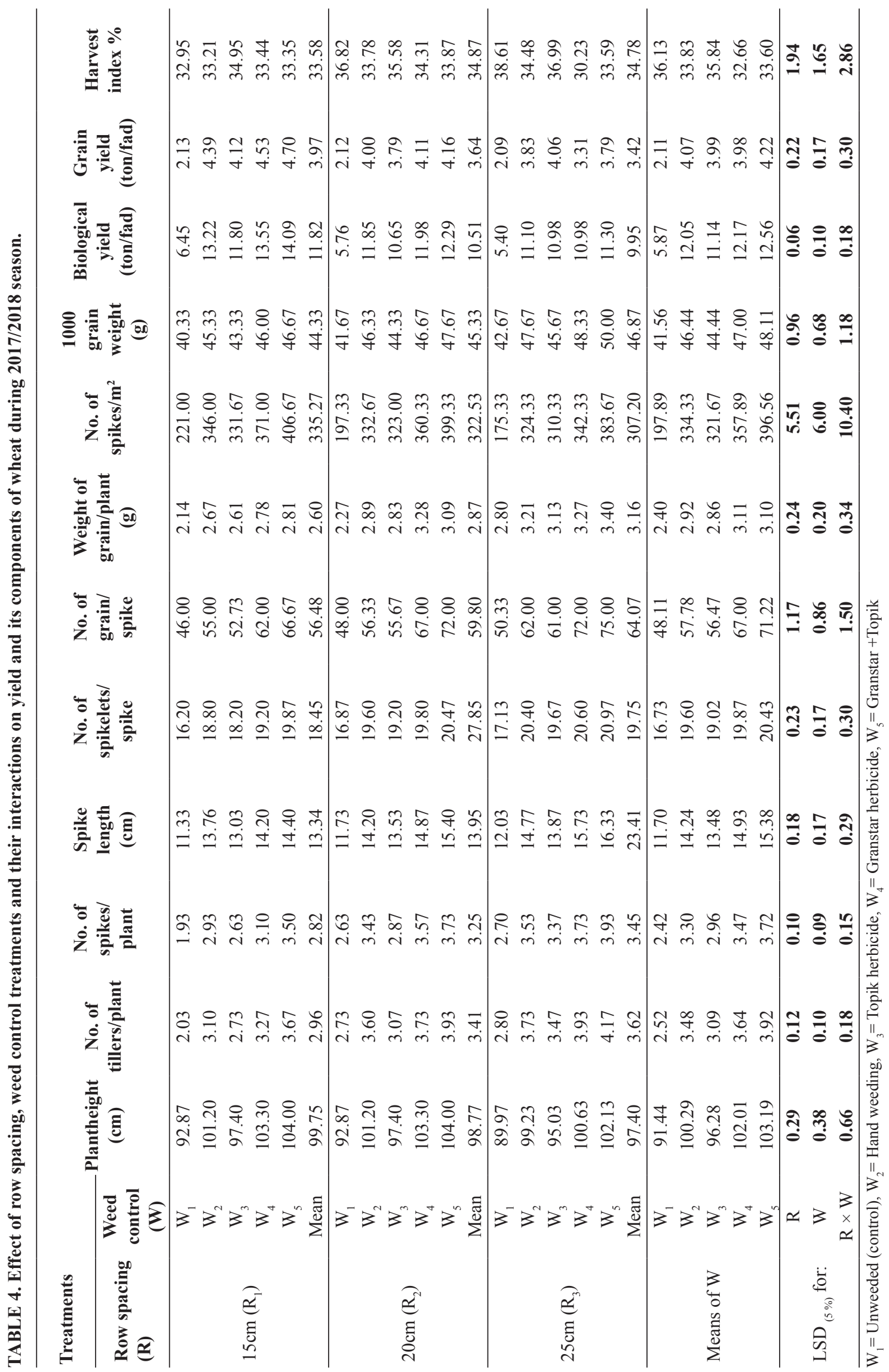

Egypt. J. Agron. Special Issue (2018) 
Each shortening in row spacing increased plant height (100.47 and $99.75 \mathrm{~cm})$, number of spikes $/ \mathrm{m}^{2}$ (347.77 and 335.25spikes $\mathrm{m}^{-2}$ ), biological yield (10.13 and 11.82ton/fad) and grain yield (3.40 and $3.97 \mathrm{ton} / \mathrm{fad})$ in both seasons, respectively. However, other treats were decreased when wheat was sown in narrow row spacing $15 \mathrm{~cm}$ or $20 \mathrm{~cm}$ compared with wide row spacing $25 \mathrm{~cm}$.

Planting wheat in row spacing $15 \mathrm{~cm}$ caused $3.97 \%$ and $16.08 \%$ increases in grain yield (ton/ fad) over the lowest yielding row spacing, i. e. $25 \mathrm{~cm}$ in the first and second season, respectively. These results are in agreement with those recorded by Ali et al. (2010). Increasing plant height under dense planting when sown wheat in $15 \mathrm{~cm}$ row spacing may be due to the intraspecific competition among crop plants for capturing light. Furthermore, wider row spacing ensure more available share of the environmental resources required for plant growth, so increasing yield components. However, the increment in plant number per unit area and the less weed growth with narrow row spacing may be responsible for the resultant increase in wheat yields.

\section{Conclusion}

Higher grain yield was recorded from $15 \mathrm{~cm}$ row spacing than $25 \mathrm{~cm}$. The higher grain yield in $15 \mathrm{~cm}$ row spacing was achieved mainly due to more number of spike $\mathrm{m}^{-2}$ over other row spacing. As well as, hand weeding twice followed by post -emergence application of Granstar at the rate $8 \mathrm{~g} / \mathrm{fad}+$ Topik at the rate $140 \mathrm{~g} / \mathrm{fad}$, supported the control against dry weight of grassy, broadleaved and total weeds and improved wheat grain productivity.

\section{References}

Ali, M., Ali, L., Sattar, M. and Ali, M.A. (2010) Improvement in wheat (Triticum aestivum L.) yield by manipulating seed rate and row spacing in Vehaizone. J. Anim and Plant Sci. 20, 225-230.

Babaei, M. and Saeedipour, S . (2015) Effect of seed rate and post emergence herbicide application on weed infestation and subsequent crop performance of wheat (Triticum aestivum L.). Walla, J. 31(53), 158-162.

Bibi, K.B., Hassan, G. and Maula, N.K. (2008) Effect of herbicides and wheat population on control of weeds in wheat. Pakistan J. Weed Sci . Res. 14(34), 111-119.

Drews, S., Neuhoff, D. and Koepke, U. (2009) Weed suppression ability of three winter wheat varieties at different row spacing under organic farming conditions. Weed Res. 49, 526-533.

FAO (Food and Agriculture Organization of the United Nations) (2016) FAOSTAT: World Crop Production data.

Genene, G and Habtamu, S. (2001) Agronomic research recommendation and seed production maintenance techniques for major crops training manual for DA of highland Bale Sinan-Ethiopia: 9-15.

Gomez, K.A. and Gomez, A.A. (1984) "Statistical Procedures for Agriculture Research". $2^{\text {nd }}$ ed. John Wiley and Sons. New York, USA. 680pp.

Hussain, I., Khan, M.A. and Ahmad, K. (2003) Effect of row spacing on the grain yield and the yield component of wheat (Triticum aestivum L.). Pakistan Journal of Agronomy, 2(3), 153-159.

Mahmud, M.Sh., Morsy, A.S. and Fakkar, A.A.O. (2016) Evaluation of some bread wheat cultivars under different seeding rates and weed control treatments. J. Plant Production, Mansoura Univ. 7(12), 1339 -1348 .

Mekdad, A.A.A. (2015) Effects of planting dates, foliar micronutrients mixture rates and weeding regimes on performance of sesame crop (Sesamum indicum L.). J. Plant Production, Mansoura Univ. 6(12), 2103-2121.

Shaban, Sh.A., Soliman, S., Yehia, Z.R. and ElAttar, M.H. (2009) Weed competition effect on some (Triticum aestivum) quality and quantity components. Egypt. J. Agron. 31(2), 135-147.

Sharma, S.N. and Singh, R.K. (2011) Seed rate and weed management on yield and nutrient uptake of wheat (Triticum aestivum). Indian Journal of Agricultural Sciences, 81(12), 1174-1179.

Shehzad, M.A., Nadeem, M.A. and Iqbal, M. (2012) Weed control and yield attributes against post emergence herbicides application in wheat crop, Punjab, Pakistan. Global Advanced Res. J. Agric. Sci. 1(1), 7-16. 
Soliman, I.E., Abd El-Hamid, G.M. and Fadl-Allah, A.M. (2011) Effect of herbicides and urea as additive on wheat, nutrient uptake, photosynthetic pigments and associated weeds. J. Plant Production, Mansoura Univ. 2(1), 1393-1407.
Tompkins, D.K., Hultgreen, G.E., Wright, A.T. and Fowler, D.B. (1991) Seed rate and row spacing of no-till winter wheat. Agron. J. 83, 684-689.

(Received 21/10/2018;

accepted 4/12/2018)

\section{تأثير المسافة بين السطورمع أو بدون مكافحة الحشائش على القمح فوزي سيد عبد السميع، اكرام على مجاور، على عبد الله على مقداد و ساره محسن محمد

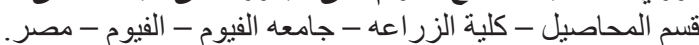

أقيمت تجربتان حقليتان بمزرعة كلية الزراعة جامعة الفيوم بناحية دمو خلال موسمي 2017/2016

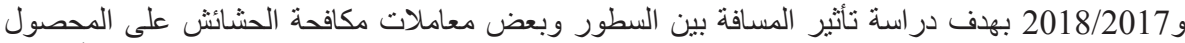

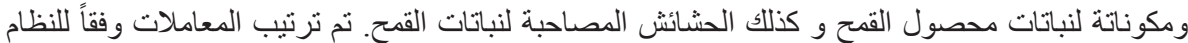

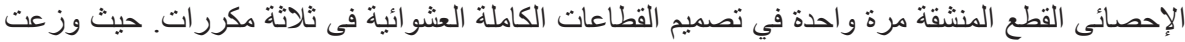
المسافة بين السطور في القطع الرئيسية ومعاملات مكافحة الحشائش في القطع المنشقة .

أظهرت النتائج أن معاملات المسافة بين السطور اثرت معنوياً على الوزن الجاف للحشائش (جم/م²)

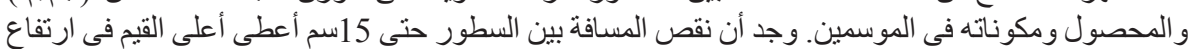

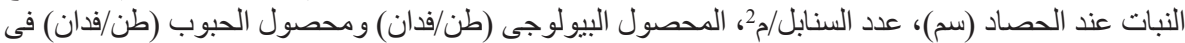

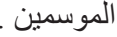

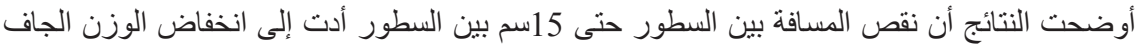

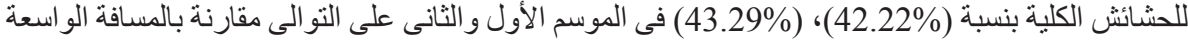

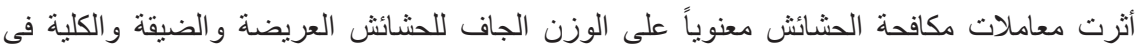

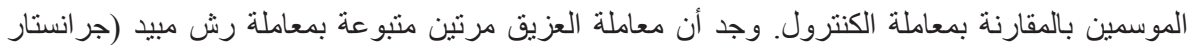

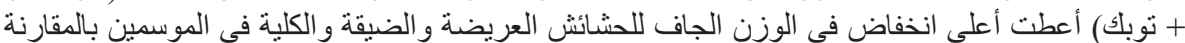

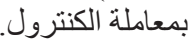

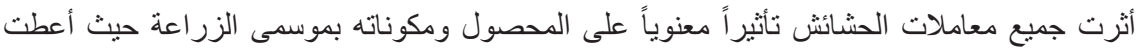

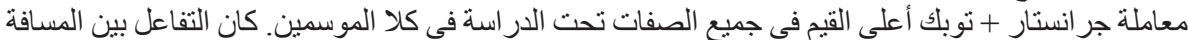

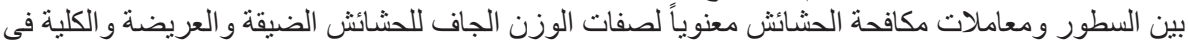

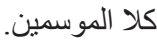

و على ضوء نتائج هذه الدر اسة فان زر اعة القمح فى سطور ضيقة 15سم وتطبيق مبيد الجر انستار مع التوبك

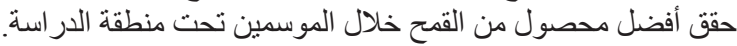

